N13 _ Ardeth

A magazine on the power of the project

$6 \mid 2020$

Contingency

\title{
Indigeneity, Contingency, and Cognitive Shifts
}

\section{Kelema Lee Moses}

\section{(2) OpenEdition}

\section{Journals}

Electronic version

URL: http://journals.openedition.org/ardeth/1171

ISSN: 2611-934X

Publisher

Rosenberg \& Sellier

Printed version

Date of publication: 1 September 2020

Number of pages: 121-134

ISSN: 2532-6457

Electronic reference

Kelema Lee Moses, «Indigeneity, Contingency, and Cognitive Shifts », Ardeth [Online], 6 | 2020, Online since 01 November 2020, connection on 13 November 2020. URL : http://journals.openedition.org/ ardeth/1171 


\section{Indigeneity, Contingency, and Cognitive Shifts}

Kelema Lee Moses

Abstract

When architects and architectural historians stray from contingent forces that are an inherent part of architecture and place-making processes, they miss opportunities to incorporate multivalent imaginaries that allow for change and flexibility in architectural production. This article maintains that centering Indigenous voices in the development of built environments and in the study of architectural histories allow for a (re)imagining of the transformative potential of contemporary architecture. First Nation and Native American epistemologies decenter Western conceptions about architecture's ordered and universalizing qualities and, instead, emphasize the interconnectedness (physical, social, emotional, spiritual, and intellectual) between people and landscapes. The essay further maintains that embracing collaborative partnerships between Native and non-Native architects will result in cognitive shifts toward innovative design solutions to address twenty-first century issues related to climate change and the creation of inclusive communities that lift up societies.
Affiliation:

Occidental College, Department of Art and Art History

\section{Contacts:} mosesk [at] oxy [dot] edu

Received: 06 September 2019

Accepted:

16 April 2020

DOI:

10.17454/ARDETH06.10

ARDETH\#06 


\section{Indigenous voices} allow for a (re)imagining of the transformative potential of contemporary architecture.

\section{Introduction}

The April 2019 edition of ByDESIGN features the cover story, “Anjelica Gallegos, Charelle Brown, Summer Sutton: Yale's Indigenous Scholars of Architecture, Planning \& Design.” The College of Environmental Design at the University of California, Berkeley publishes the journal as an online forum to promote diversity within design fields. The issue spotlights the three Native American scholars' academic pursuits and their attempts to integrate Indigenous epistemologies about landscapes and built environments into the academic design curriculum in the United States. They endeavor to create an inclusive environment for students of color and attract diverse faculty to the profession. The crux of their initiatives involves course development whereby faculty and students work together to counter Western narratives that have often relegated Indigenous knowledge to the past. Emphasizing Indigenous systems as a continuum of thought inherently tied to the preservation of natural resources rearranges existing architectural conditions that define the political and social functions of architecture as means to definitive ends: residential plans for housing, public edifices for communal gathering, commercial dwellings for economic pursuits, and/or mixed use facilities for public-private use. While these "realities" of architectural construction are inescapable, as Gallegos (Santa Ana Pueblo and Jicarilla Apache Nation) ${ }^{1}$ reminds us, it is also important to remain "curious about the unknown of architecture because design has power to carry out ideas from any individual” (Hernández, 2019: 7). The open, collaborative approach to Indigenous design practices to which Gallegos alludes buttresses Brown's (Santo Domingo Pueblo) call to "abandon paternalistic design mechanisms” (Hernández, 2019: 5). Gallagos, Brown, and Sutton (Lumbee) underscore the importance of Indigenous knowledge to design conversations and processes that will ensure architecture's capacity to "create answers and question possibilities" from the perspective of marginalized communities (Hernández, 2019: 8). Architecture’s potential for multivalent inquiry disrupts systematic forms that have defined Western architectural successes by their Vitruvian emphasis on regularity and order. Indigenous voices in architecture and architectural histories allow for a (re)imagining of the transformative potential of contemporary architecture. 
Indigenous peoples around the world have developed heuristic and evolving knowledge systems entrenched within the landscape. According to Aileen Moreton-Robinson (Goenpul) and Maggie Walter (Palawa) (2009), knowledge systems informing Indigenous worldviews reaffirm specific Native epistemologies (ways of knowing), ontologies (ways of being), and axiologies (ways of doing). Philosophies and practices of Native worldviews are embedded within distinct cultural protocols, languages, and structural systems. These knowledge frameworks are socially constructed, influenced by varied dispositions and life experiences. This essay navigates the ties between indigeneity and architecture within a North American context where there is a shared historiography of Anglo-American land seizure. Indigenous peoples, cultures, and histories have always crossed the geopolitical borders established by the settler-colonial nations of the United States and Canada. Amid these foreign interruptions, pre- and post-Western contact Indigenous builders crafted purposeful dwellings on the land. Vernacular edifices expressed complex relationships between physical and social environments. Designers built structures to accommodate their lifestyles and changing needs, utilizing their own technology, labor, and skills to support their social organization and interactions.

A focus on the ways in which contemporary architects and thought leaders seek to disrupt linear narratives about (settler)colonialism and land seizure in the U.S. and Canada creates potential to reimagine architecture and its future. Indigenous research and frameworks have the capacity to impact policies and practices that directly affect rural and urban communities to which Native people belong. Indigenous design thinking works to the benefit of Native businesses, reservations, and homesteads. It is one path toward sovereignty, a way to reclaim what Indigenous space can/should look like. A reimagined architectural lexicon that centers Indigenous knowledge further challenges academics to question notions of Western order and structure. If architects and historians consider built environments as part of the possible, architecture is released from linear time constraints and enters relational discourses that connect various temporal and socio-spatial worlds. Students and

\section{Vernacular edifices expressed complex relationships between physical and social environments.}




\section{The legacy of colonial encounters in the development of nation-states, ties architecture's determinative quality to notions of money and property.}

practitioners can approach architectural history and theory through multiple vantage points that broaden the scope of what counts as architectural knowledge. On the one hand, Walter Benjamin's (1989) discussion of "historical time" offers a confluence of the "then" and the "now," allowing for the yet unseen. Such articulation provides one vantage point for architecture to reflect visual ruptures and subjectivities. On the other hand, Indigenous epistemologies situate the land as the dominant feature of time and place. Sandra Styres (Kanien-kehá:ka) (2019) reminds us that land is storied, it can be read in ways that reveal ancestral teachings and "ideologies of rational thought" (28). From this premise, as revealed by Tiffany ShawCollinge's (2018) transcription of an interview with Wanda Dalla Costa (Saddle Lake First Nation), Indigenous communities ask an unfamiliar question related to the land: "how do [Native] meanings associated with words such as 'building,' 'construction,' or 'design£ translate [to] visual language in architecture"? Foregrounding the dynamic relationship between diverse interpretations of space, place, and time will transform who and what is included within academic discourses, as well as the ways in which architects practice a craft that inherently rejects the contingent the unseen, unfamiliar, and unknown.

\section{Architecture as Noun, Architecture as Verb}

Centering Indigenous communities within contemporary architectural dialogue recognizes the legacy of colonial encounters in the development of nation-states, which ties architecture's determinative quality to notions of money and property. John Locke's early modern theories defined and measured civilization(s) based on the cultural and political outcomes of economic activity. Money undergirded trade practices that (re)established social categories and created what Jessica A. Cattelino (2018) has called the temporality of desire, the notion that individual and familial wants could be extended into the future given that currency does not expire. Money and its compatriot, property, served to cultivate physical landscapes and increase human productivity. From the juncture of money and property, Enlightenment era theories about individuality and reason arose from the supposition that those who implemented this mindset were 
the arbiters of civilization. For those who fell outside of these parameters such as First Nations, Native Americans and Pacific Islanders, whose societies were largely based on kinship ties knitted together by unowned, "uncultivated" land, the Western construct of civilization did not apply. Rather than serving as stewards of the land with a cultural responsibility to nurture the terrain, Western landed elites with monetary resources erected monumental permanent edifices for public recognition that have come to connote the physical embodiment of civilization.

The Western desire to categorize spaces and places is one mode of constructing boundaries and territories for the purpose of organization. A focus on physical space can be utilized by individuals and the nation for political ends and can also function as a conduit for the creation of culture. Paul Carter declares as much in The Road to Botany Bay (1987). His study of the Australian landscape advances Yi-Fu Tuan's study about place. Whereas Yi-Fu reveals in Space and Place: The Perspective of Experience (1977) that places are imbued with meaning once they are affected by human experience, Carter maintains that in the context of Western imperial frameworks, a place is merely "a stage that pays attention to events," a revelation that leads him to assert that, in order for places to have historical relevance, a "cause and effect" paradigm must exist such that order can emerge from chaos. Pawel Rubinowicz (2000) from the Institute of Architecture and Spatial Planning in Poland defines architectural order as "ideal mathematical forms and ideal relationships” while architectural chaos connotes complex relationships that are "difficult to describe with the language of classical mathematics" (197). The symbiotic relationship between order and chaos allows for spatial diversity and complexity such that the balance between the two is necessary for the construction of stable compositions. However, if we reframe the order-chaos paradigm that emphasizes stability into a model that embraces the contingent, or the uncertain, architectural narratives about adaptability and change tied to legacies of (neo)colonialism emerge.

Western colonization and imperial development of North America resulted in Indigenous dispossession. Within Indigenous communities, rich architectural

\section{The Western desire to categorize spaces and places is one mode of constructing boundaries and territories for the purpose of organization.}


To discuss indigeneity within the context of built environments is not to essentialize or universalize indigenousness traditions rooted in genealogies and specific environmental concerns adapted as societies consistently sought to protect beliefs and practices caught in the onslaught of disease, death, and loss of land in the post-contact era. This historical construct has led U.S.-educated, Pacific Island scholars such as David Welchman Gegeo (Kwara'ae and Lau) to pose questions about the connection between Indigeneity and space/place. Gegeo poignantly asks: "Is indigeneity a matter of physical space? Or is it a cognitive or cultural place? Or both?” (Gegeo, 2001: 495). His analysis pertaining to the "portability of place" suggests that the politics of identity should not outweigh the nature of indigeneity - "a cultural group's ways of thinking and of creating and reformulating knowledge, using traditional discourses and media of communication" (Gegeo, 2001: 493). Thus, the nature of indigeneity is not singularly rooted in a temporal or defined spatial form but has been both historically and contemporaneously rooted and routed among vast geographies. Wars, manifest destiny theories, natural disasters, and community autonomy have all contributed to Indigenous movement and settlement adaptable to changing circumstances.

To discuss indigeneity within the context of built environments is not to essentialize or universalize indigenousness but rather to feature Indigenous thought leaders who are helping to shape the field either in a traditional, academic sense or in ways that involve activism, public relations, and/or community organizing. The Standing Rock Syllabus, as one example, provides a critical framework for a nuanced approach to contingency within the curricular development of architectural studies. The impetus for the syllabus arose after the U.S. Army Corps of Engineers finalized permits to construct the Dakota Access Pipeline (DAPL), a crude oil aqueduct stretching from North Dakota to Illinois. In addition to violating environmental statutes and historic preservation mandates, the pipeline would infringe upon the sovereignty, sacred sites, and burial grounds of the Sioux tribe's Standing Rock Reservation. A consortium of Indigenous peoples and nations, settlers, and people of color built upon the preexisting work of Native American communities in resisting DAPL to draft the syllabus. The syllabus opens with a preface about the pipeline as a call for 
solidarity. It then offers key terms, a map of Native American territorial and treaty boundaries, a timeline of U.S. settler colonialism, and readings organized by theme and topic. The involvement of architecture and urban studies faculty from Columbia University, The New School and Yale, in the form of letters of support, demonstrated commitment on the part of educators to lay bare the deleterious repercussions of "neoliberal development projects" and the ongoing pursuit of "U.S. neocolonial interests" (Concerned Faculty, 2016: 2). The syllabus' form, as an act of collaborative innovation, exemplifies contingencies possibilities within place-making processes. The organic nature of the syllabus' formation in response to contemporary events encourages architects and architectural historians to present the document to their students as a "work in progress," one that continuously evolves with new documents and media. Various textual and visual resources associated with the construction/delay of the pipeline and its aftermath (i.e. successive oil leaks) can be included within established courses and syllabi. In doing so, conceptualizing the built environment as a fluid endeavor to be both experienced and taught enters wider national and global discourses. The Standing Rock Syllabus accounts for contingency's multivalent imaginary, a mode by which humans are motivated to action through creative and deft processes. When architecture is positioned as a noun, as a static entity devoid of dynamism, it becomes divorced from its potential to function as an active embodiment of ideas and experiences. Architecture's focus on the object, on the completed endeavor, produces constructs of legibility predicated on aesthetic values and pure forms attached to a Western moral order. However, as Sarah Hunt (Kwagiulth) (2014) contends, the converse "illegibility" of Indigenous knowledge about the material world and its environs are the result of epistemic violence. The status of money and private property as the harbinger of civilization facilitated the dehumanization of Indigenous epistemologies about spaces and places and, thus, their illegibility to the Western world. These observations are made not to perpetuate the colonizer/colonized binary but to remedy the neocolonial, neoliberal present that, perhaps, constrains attempts by architects and architectural historians to embrace contingency. That contingency aligns with
Architecture's focus produces constructs of legibility predicated on aesthetic values and pure forms attached to a Western moral order. 


\section{A cognitive shift, may serve to upend contingency's perceived illegible, irrational qualities.}

the "not necessary" or the "irrational," as Jeremy Till (2009) explains, is not divorced from the descriptor of illegibility attached to indigeneity.

Architectural practice and architectural histories that account for multiple ways of knowing the world anchored in community practices, rituals and relationships challenge contingency's aforementioned construct. A cognitive shift, or a broadening of philosophical and epistemological scope, to consider fruitful lines of inquiry born from Indigenous knowledge may serve to upend contingency's perceived illegible, irrational qualities. This approach curbs the abstracted thinking that contingency abhors; it simultaneously accepts the validity of multiple ways of knowing. Indigenous storytelling and oral traditions function as collective memories to decolonize histories that have silenced communities. The potential to decolonize architecture and its histories departs from strictly theoretical enterprises to become operational modes of creation. Brainstorming processes and implementing projects by Indigenous participants - that is, centering Indigenous people themselves as planners, architects, and designers - offer counter realities to the unquestioned normalcy of architectural academic training. To start and end with Indigenous epistemologies about buildings and landscapes allow those within the field to rethink architectural knowledge. Contingency's order-chaos binary is thereby challenged, revealing a host of opportunities to transform contemporary architecture.

\section{Indigenous Worldviews}

Indigenous scholars and architects are not beholden to colonial frameworks. Many have chosen to provide guidance and work in collaboration with non-Native people in order to, as Sarah de Leeuw and Sarah Hunt (2018: 9) proclaim, “make Indigenous people’s lived realities more visible on their own terms as an expression of self-determination". In line with this claim, Douglas Cardinal, a Blackfoot/Kainai and Algonquin architect and critic, made the following remarks upon the opening of Canada's first Indigenous entry to the 2018 Venice Architecture Biennale: "I firmly believe that the indigenous world view, which has always sought a balance between nature, culture and technology, is the path that humanity must 
rediscover and adopt for our future. The teachings of the elders are not the teachings of the past. They're lessons for the future" (Kassam, 2018). Collaborative efforts and intersectional dialogue between clients, practitioners, and historians emphasize Indigenous ways of knowing as a process rather than a compilation of specific content (Berkes, 2009: 152-153). As an example, ecology and climate science provide another framework for architectural pedagogies to integrate Indigenous knowledge. The Cree people of Wemindji (Canada) and Kanaka Māoli (Native Hawaiians) have, for decades, recognized climate change as a force affecting landscapes and built environments. Through close observation of geographies to which they are intimately tied and the transference of generational knowledge, the communities have learned to pinpoint signs and signals pertaining to changes in the environment. The co-production of knowledge produced in collaboration with Western researchers have led to advancements in resource management and planning, community health projects, environmental monitoring, and demarking areas for biodiversity conservation (Berkes, 2009).

Knowledge co-production between committed stakeholders reflect the point at which contingency aligns with certainty. Academic institutions are slowly recognizing the importance of "co-writing, co-teaching, and co-learning" - to borrow the language of Ana María León (2018). For non-Indigenous educators, learning how architecture and (neo)colonialism work together is a critical need and creates a foundation for building productive, reciprocal relationships with Indigenous peoples and knowledges. Indigenous participants contribute to culturally sustaining and revitalizing practices. For example, Sean Connelly (Pacific Islander American) developed Hawai' $i$ Futures, an educational tool consisting of digital performance maps and architectural prototypes to understand Hawai'i's changing urban landscape through virtual interventions. Connelly's theoretical model, often used by students at Harvard's Graduate School of Design, can be juxtaposed with tangible interventions by Indigenous design teams. As such, the building expansion program at the Ontario College of Art and Design University (OCAD) involved Two Row Architect, a 100\% Native-owned and operated design firm from the Six

\section{Academic institutions are slowly recognizing the importance of "co-writing, co- teaching, and co- learning”.}




\section{Mutually beneficial relationships allow for inventive results that deviate from contemporary architecture's expected norms and outcomes.}

Nations reserve in southern Ontario. Their participation in the OCAD project injected a Native American Methodology, one committed to designing with "passion, respect, and responsibility" so as to "achieve a level of sustainable development allowing for future generations to live with the same natural resources that are available today" (Two Row Architect). The work of Connelly and Two Row Architect supports Patrick Stewart's (Luugigyoo) comments to Daniel Viola (2017) in Azure magazine, "If you're going to talk about architecture and you're going to talk about Indigenous communities, then you need to involve Indigenous architects.”

Mutually beneficial relationships allow for inventive results that deviate from contemporary architecture's expected norms and outcomes. Native and non-Native architects, artists, and those with a vested interest in the built environment operate as a bridge between the public and private realms, addressing both creative freedom and architectural rigidity. Designers craft edifices that audiences encounter as experiences that are unconstrained from Western architectural expectations, spatially and temporally. Individuals draw from their knowledge of art, history, theater, science, math, etc. in order to develop their own experiential analysis. This type of mutually beneficial relationship in architecture resists the trap of "studying” Indigenous communities as ethnographic, anthropological projects. In this way, a critical reflection of architectural pedagogies and practice reveal that "liberal education is not culture-free" nor does it occupy "an ideological neutral high-ground,” as Tongan poet and scholar Konai Helu Thaman (2003: 7) maintains. Advancing Thaman's claim, architecture encompasses cultural beliefs and values entrenched in curricula and agendas. Architecture, as a system of representations within this schema, makes claim to the universal and ordered significance of its output. Thaman, in her own words, further points out Max Weber's contention that while a system [science] "makes the world orderly it does not necessarily make it meaningful” (2003: 6). Therefore, a paradigm shift in the way that contingency is understood in the architectural field requires critical interrogation of images and representations through manifold lenses of truth that transcend cultural boundaries. 
The partnership between Terrol Dew Johnson (Tohono-O'odham Nation) and the New York-based design studio of Aranda|Lasch demonstrates one architecture firm's ability to navigate contingency discourses. When Aranda $\backslash$ Lasch endeavored to innovatively rethink the meaning of objects within an architectural framework, they forged a relationship with Johnson, an illustrious basket-weaver, educator, and activist. In the basket weaving genre, patterns, materials, and shapes drawn from local environmental settings offer both aesthetic and utilitarian function. Johnson's compositions reflect the interconnectedness between native life and landscape. As Johnson describes to Catherine K. Hunter (2012):

In the Tohono O'odham language, we have no word for art. My ancestors never really created formal artwork that was separated from day-to-day life. Instead, Native people have always looked to create artful ways of living, seeking ways to blend beauty and usefulness. We try to live in ways that bring together the material, spiritual and aesthetic worlds. In basketry, beauty and utility are joined together. Some call it art; most basket weavers simply call it life...

Conversations between Johnson and Aranda|Lasch led to design experimentation. The collaborators thought about the connections between the living tradition of Native American basket-weaving and advancements in digital fabrication. The architects noted the ways in which Johnson's work emphasized the voice of a people through their systems and their methods. Intricate basket weaving techniques from plaiting to twining to coiling created dynamic assemblages that Aranda $\backslash$ Lasch interpreted as complex algorithms. The algorithms formulated by computer programming modules, paired with Johnson's skills, resulted in a series of contemporary baskets now housed in New York City's Museum of Modern Art (MoMA). The cooperative enterprise between Johnson and Aranda $\backslash$ Lasch also resulted in the project's inclusion in the 2017 Chicago Architecture Biennial. The event highlighted the ways in which the partners transitioned the weaved baskets into large-scale furniture and architectural projects including simple shelters and an outdoor music venue. Native understandings about the effects of climate change on desert communities inspired these
A paradigm shift requires critical interrogation of images and representations through manifold lenses of truth that transcend cultural boundaries. 
designs, and others, as Johnson called on the architectural profession to utilize natural resources (i.e. mud and vegetation) and renewable energy so that the general public can visibly understand how "collaborations [can] better the community, the environment, and architecture” (Huang and Shaw, 2017).

\section{Conclusion}

This essay outlines the ways in which Indigenous thinking and voices can transform the fields of architecture and architectural history. It does not suggest that Indigenous knowledge be superfluously extracted for non-Native use but offers a framework for shifting from architecture's streamlined processes and outcomes to a mode of thinking that earnestly seeks out architectural variation, as well as philosophical and epistemological approaches to the built environment. In destabilizing normative discourses in academic curricula and architectural practice, place-making is no longer centered on re-making or mimicking the status quo; place-making, instead, produces built environments that are open to manipulation and varied, changing usage. What results are collaborative, inclusive contemporary architectures that uplift societies and support interdependent ecosystems.

\section{References}

Benjamin, W. (1989), Critical Theory and Society. A Reader, Bronner, Kellner, D. M. (eds), New York - London, Routledge, pp. 255-263.

Berkes, F. (2009), Indigenous ways of knowing and the study of environmental change, "Journal of the Royal Society of New Zealand", vol. 39, n. 4, pp. 151-156.

Carter, P. (2013), The Road to Botany Bay: An Exploration of Landscape and History, Minneapolis, University of Minnesota Press.

Cattelino, J. R. (2018), From Locke to Slots: Money and the politics of indigeneity, "Comparative Studies in Society and History”, vol. 60, n. 2, pp. 274-307.

Çinar, Z. (2014), Contingent Presences in Architecture: Vitruvian Theory as a Beginning, "World Academy of Science, Engineering and Technology, International Journal of Social, Behavioral, Educational, Economic, Business and Industrial Engineering”, vol. 8, n. 4, pp. 1132-1136.

Concerned Faculty, Columbia University (2016), A Statement of Support for the Standing Rock Sioux Tribe, "Standing Rock Syllabus" [Online]. Available at: https://nycstandswithstand- 
ingrock.files.wordpress.com/2016/10/columbia- faculty-support-letter-standing-rock.pdf [Accessed: 8 November 2019].

De Leeuw, S., Hunt, S. (2018), Unsettling decolonizing geographies, “Geography Compass”, vol. 12, n. 7, pp. 1-14.

Gegeo, D. W. (2001), Cultural rupture and indigeneity: The challenge of (re) visioning" place" in the Pacific, "The Contemporary Pacific”, vol. 13, n. 2, pp. 491-507.

Goldstein, A. (2008), Where the nation takes place: Proprietary regimes, antistatism, and US settler colonialism, "South Atlantic Quarterly”, vol. 107, n. 4, pp. 833-861.

Hernández, R. (2019), Anjelica Gallegos, Charelle Brown, Summer Sutton Yale's Indigenous Scholars of Architecture, Planning \& Design, “By Design”, n. 30, pp. 4-9.

Hewitt, M. A. (1994), Architecture for a contingent environment, "Journal of Architectural Education", vol. 47, n. 4, pp. 197-209.

Hokowhitu, B. (2013), Producing Indigeneity, in Peters, E. and Andersen, C. (eds), Indigenous in the City: Contemporary Identities and Cultural Innovation, Vancouver, University of British Columbia Press, pp: 354-376.

Huang, E. and Shaw, L. (2017), How Terrol Dew Johnson and Aranda $\mid$ Lasch are reinventing basket-weaving traditions to sustain native culture and community, "ArchDaily" [Online]. Available at: https://www.archdaily.com/877933/how-terrol-dew- johnson-and-aranda-lasch-are-reinventing-basket-weaving-traditions-to-sustain- native-culture-and-community/ [Accessed: 10 August 2019].

Hunt, S. (2014), Ontologies of indigeneity: The politics of embodying a concept, "Cultural Geographies", vol. 21, n. 1, pp. 27-32.

Hunter, C. (2012), Artist Profile: Terrol Dew Johnson [Online]. Available at: http://nationalbasketry.org/artist-profile-terrol-dew-johnson/ [Accessed: 12 August 2019].

León, A.M. (2018), Crowdsourcing knowledge: Cowriting, coteaching, and colearning, "Art Journal Open," [Online]. Available at: http://artjournal.collegeart.org/?p=10593 [Accessed 10 August 2019].

Locke, J. (2015 [1689]), On property, in Bailey, A. (ed.), The Second Treatise of Civil Government, Ontario, Broadview Press, pp. 43-54.

Matunga, H. (2018), A discourse on the nature of indigenous architecture, in E. Grant, K. Greenop, A. Refiti, D. Glenn (eds), The Handbook of Contemporary Indigenous Architecture, Springer, Singapore, pp. 303-330.

McGaw, J., Pieris, A., Potter, E. (2011), Indigenous place-making in the city: Dispossessions, occupations and implications for cultural architecture, "Architectural Theory Review", vol. 16, n. 3, pp. 296-311.

Moreton-Robinson, A. and Walter, M. (2009), Indigenous methodologies in social research, "Social research methods", n. 2, pp. 1-18. 
Nichols, R. (2014), Contract and usurpation: Enfranchisement and racial governance in settler-colonial contexts, in A. Simpson and A. Smith (eds), Theorizing Native Studies, pp. 99-121. Ram, M. (2014), White but not quite: normalizing colonial conquests through spatial mimicry, “Antipode”, vol. 46, n. 3, pp. 736-753.

Rubinowicz, P. (2000), Chaos and geometric order in architecture and design, "Journal for Geometry and Graphics", vol. 4, n. 2, pp. 197-207.

Shaw, W. S., Herman, R. D. K., Dobbs, G. R. (2006), Encountering indigeneity: Re-imagining and decolonizing geography, “Geografiska Annaler”, vol. 88, n. 3, pp. 267-276.

Shaw-Collinge, T. (2018) Indigenous Perspectives of the Notions of Architecture, "The Site Magazine" [Online]. Available at: https://www.thesitemagazine.com/read/indigenous-perspectives [Accessed: 23 March 2020]. Styres, S. (2019), Literacies of Land: Decolonizing Narratives, Storying, and Literature, in L. T. Smith, E. Tuck, K. W. Yang (eds), Indigenous and Decolonizing Studies in Education: Mapping the Long View, New York - London, Routledge.

Teaiwa, T. (2014), The ancestors we get to choose: White influences I won't deny, in A. Simpson, A. Smith (eds), Theorizing Native Studies, pp. 43-55.

Thaman, K. H. (2003), Decolonizing Pacific Studies: Indigenous Perspectives, Knowledge, and Wisdom in Higher Education, “The Contemporary Pacific", vol. 1, n. 1, pp. 1-17.

Till, J. (2008), Architecture and contingency, "Field”, vol. 1, n. 1, pp. 120-135.

Tuan, Y.F. (1977), Space and Place: The Perspective of Experience, Minneapolis, University of Minnesota Press.

Two Row Architect, “Our Story” [Online]. Available at: https:/ www.tworow.com/about-us [Accessed: 20 March 2020]. Viola, D. (2017), Canada 150: The Integral Role of Indigenous Architects, "Azure Magazine" [Online]. Available at: https:// www.azuremagazine.com/article/indigenous- architects-canada/ [Accessed 25 July 2019]. 